Trans

continentales

\title{
Transcontinentales
}

Sociétés, idéologies, système mondial

$10 / 11 \mid 2011$

La ruée vers la terre

\section{The land rush}

Transnational strategies for land grabing

\section{Boris Petric}

\section{OpenEdition}

\section{Journals}

Édition électronique

URL : http://journals.openedition.org/transcontinentales/1303

DOI : 10.4000/transcontinentales. 1303

ISBN : 978-2-7351-1572-3

ISSN : 1775-397X

Éditeur

Editions de la maison des sciences de l'homme

\section{Référence électronique}

Boris Petric, «The land rush », Transcontinentales [En ligne], 10/11 | 2011, mis en ligne le 21 décembre 2011, consulté le 23 septembre 2020. URL : http://journals.openedition.org/transcontinentales/1303 ; DOI : https://doi.org/10.4000/transcontinentales.1303

Ce document a été généré automatiquement le 23 septembre 2020.

Tous droits réservés 


\title{
The land rush
}

\author{
Transnational strategies for land grabing
}

\section{Boris Petric}

1 Over the last decade, a global land market in the agricultural and rural domains has emerged. States, multinational corporations and financial investors are seeking to acquire or control by purchase or lease agricultural areas in different regions around the world. These farms, which can cover several thousand hectares, serve different strategies. States justify these acquisitions by citing the food shortages their societies must come to terms with. Multinational corporations aim to increase their control over global raw material production in order to boost their development. Investors see land and raw materials as safe investments or even speculative opportunities in the context of today's financial crisis. These shifts in controlling production, which also reflect shifts in organising the market and regulations, have an impact on land issues in different societies.

2 As a result of recent events, this trend has been given considerable media coverage. It is as if we were witnessing a giant Monopoly game on a global scale.

3 One example is the international firm Benetton ${ }^{1}$, currently facing legal proceedings in Argentina. ${ }^{2}$ The Benetton brothers own over 900,000 hectares in Argentina, which they have used to increase production of the merino wool they need to expand internationally their textile production. The Argentinian government's agreement to hand over this land to the Italian brand took the local Mapuche population, which has lived and farmed the region for centuries, by surprise. The Argentinian government took this opportunity to introduce the concept of exclusive private property to a region where natural resources have never been governed in these terms. With support from local and international NGOs, Mapuche leaders have begun legal proceedings against the Italian firm and the Argentinian government.

4 This situation is evidence of a much more widespread process propagating a global norm like private property. It can be seen in the increasing power of bureaucracies, and therefore States, when it comes to giving control of large swathes of land to foreign parties. Some governments or bureaucracies, in collusion with transnational economic actors, tend to generalise the principle of property by giving deeds of ownership or 
leases to foreigners so that they can farm vast areas of rural land. However, many communities still consider that land cannot be disposed of and man's relationship with nature is based on various local rights of usage specific to each local reality.

5 A second example, which attracted considerable media attention, shows another trend resulting from the expansion of international agri-business: the development of powerful global economic groups. The Daewoo company, ${ }^{3}$ almost a law unto itself in South Korea, attempted to take control of thousands of hectares of land in a bid to extend its agricultural activities in Madagascar. Its aim was to grow rice and cereal crops to supply the South Korean market while increasing its ability to take part in global trade in primary food resources. Despite the fact that 6 million Madagascans ${ }^{4}$ lacked basic food resources, the Korean giant drew up a historical agreement with the Madagascan President Ravalomanana under which it would rent nearly one million hectares of arable land to produce food for export. When these negotiations were made public, they unleashed a wave of objections that forced Ravalomanana to resign from office. On 18 March 2009, the new Madagascan President, Andry Rajoelina, took the step of purely and simply cancelling the agreement by stating, "Madagascar's land is neither for sale nor for rent." It should be underlined that Ravalomanana's departure and objections to the deal had major international repercussions.

6 The Madagascar example shows two different trends that deserve our attention. First, there is a developing agri-business linked to the creation of an international market for primary food resources (rice, corn, soya, etc.) over which States have less and less influence, especially in terms of price setting. Secondly, it also shows how political movements are shifting from the local to the global level. Indeed, the political opposition in Madagascar is evidence of the growing number of situations where national political arenas are undergoing major changes in terms of the way they work. These countries are faced with strategies developed by major players in the agribusiness industry, but are also experiencing the emergence of new and unprecedented social movements, where international and transnational actors oppose agri-business strategies. These political battles are caught up in global movements that can surpass local issues. In Madagascar, many different actors including NGOs, international organisations and also powerful countries with interests in the island, relayed local discontent and helped put a stop to the Daewoo project. It should be underlined that Madagascar is not a typical political space. A new form of global political conflict based on protecting nature is emerging in the country. The island is considered important from an international biodiversity point of view, and has received unprecedented attention from the different actors seeking to protect this global heritage. While this new form of interaction did cause Daewoo's project to fail, it also creates new challenges for Madagascan society.

7 New actors emerge and react to these economic powers. Local NGOs, like the International Land Coalition, become opposition forces, battling the strategies of multinational organisations by joining forces with international NGOs to defend small farmers.

8 However, this phenomenon is not limited to occasional conflicts where transnational institutions are merely opposition powers. International agencies (the UN, the UNDP, the FAO and the World Bank) and large international NGOs are playing an increasingly important role in coproducing norms in these different societies. They are therefore part of these societies' power structures. For instance, they develop programmes that 
help spread global norms liberalising the land market, generalising private property and freedom of contract and protecting investments. One example is the American NGO Chemonics International, ${ }^{5}$ which works to privatise land and promote contracts in rural areas in societies concerned by development.

9 The same institutions aim to develop programmes protecting biodiversity and heritage by creating protected areas (zones, national parks, etc.). Despite claiming to protect the environment, these policies can make natural areas into sanctuaries, which is problematic for local populations that depend on these natural resources for their livelihoods.

10 Consequently, these different groups play a key role in controlling, managing and appropriating shared natural areas (forests, deserts and islands). They have coproduced a new form of sovereignty.

11 Over and above these highly publicised examples, it is clear that social scientists must reflect on the complexity of this new architecture of influence as it will lead to new forms of tensions affecting land on a global scale. It affects many different players, and is not limited to the issue of land being appropriated for agri-business and cattle farming by transnational companies. These trends are therefore part of a wider process involving the reformulation of sovereignty over vast areas of land within the world's different societies.

12 As far as the history of humanity is concerned, there is nothing new about foreigners seizing land. Imperialist conquests and colonialist forays often sought to control land in order to develop activities for reasons unrelated to local societies.

13 The difference is probably that, today, powerful countries are adopting land acquisition strategies that are not located in post-colonial countries. As a result, China, Japan and Saudi Arabia are seeking to control land around the world. Large American companies like Monsanto have well documented strategies, and Indian, Chinese and French agrifood companies are also currently seeking to control land around the world to expand and outsource production.

14 In addition, financial players (including banks and investment funds) now offer financial products based on acquiring land in particular countries. Two French companies are especially active in this field. Charles Beigbeder's Agrogeneration Group has invested heavily by purchasing land in Ukraine. Olivier Combastet's Pergam Finance, which is based in South America, gives international clients the opportunity to buy land in Argentina, Chile and Uruguay. These companies cannot only be considered as "national", because they develop by building up "transnational" capital. The unprecedented development of this kind of actor shows the complexity of interdependencies affecting the globalisation of trade.

One of the risks we run is adopting the denunciatory attitude used by some media to describe the threat of agrarian neocolonialism ${ }^{6}$ by reducing this process to actions by predatory Western companies. This kind of analysis overlooks the responsibilities of elite groups and national bureaucracies in implementing these social processes. We must therefore examine how transnational ties linking elite groups on different scales develop on local and global levels.

Moreover, there is a reason why many transactions are currently taking place in the post-socialist area, where bureaucracies have considerable leeway to transfer large areas of land that were previously collectively owned. The privatisation of land is 
developing as a result of new economic, social and political ties between local elite bureaucratic groups and global players.

The liberalisation currently taking place in Ethiopia is particularly revealing in this respect. In a remarkable documentary film, ${ }^{7}$ Alexis Marant illustrated this phenomena by the story of an Indian company setting up in Addis Ababa. Karuturi Global Limited managed to obtain a 50-year lease from the Ethiopian government to exploit land in the country. As the country's largest horticultural company, Karuturi Global Limited exports tulips to the Netherlands and thus increases its expansion in the global cut flower market. The Indian company also plans to grow wheat and corn to produce agrofuels. In the long run, it anticipates it will employ over 15,000 workers. Because the company exports almost all of its production, its setting up in Ethiopia has many consequences for Ethiopian society. These consequences should be studied further to understand the new situations affecting employment, conflicts over land and water use, different forms of exclusion, the strategic position of elite national groups, etc.

While this phenomenon is particularly visible in countries concerned by post-socialist transitions, it also affects other regions.

Generally, these situations are met with indifference from local populations; however, it is obvious that they can lead to new forms of conflict. New social movements appear criticising the importance of "foreigners" in the local economy and the government's role in economic regulation. One example is the Estragneros movement in Uruguay, where foreigners control one third of the country's land.

We are also currently witnessing occasional violent conflicts, such as those that affected Kyrgyzstan in 2004. People in this former Soviet republic, located at the Western border of China, rioted after learning that President Akayev had signed a secret agreement with China giving the Chinese control over a mountainous border zone where they hoped to find new water resources and new lands for pastoral activities for Chinese farmers.

21 This phenomenon is also affecting the European continent. The changing status of land has played an essential role in the construction of Europe. The liberalisation of the land market changed considerably when Eastern European countries joined the European Union. Poland, Romania and Hungary all attracted many foreign investors. Some Western European companies set up in these countries by purchasing land or signing emphyteutic leases.

This situation led to the development of national populist political movements in Poland and Hungary. It also affects societies in Western Europe, where land acquisitions by foreigners are growing in importance. In France, for example, the Chinese company CofCo recently bought a vineyard in the Bordeaux region. The American company, Mondavi has also tried to buy a huge vineyard in Aniane, a village in the South of France and was obliged to resign taking into account the local opposition of his project.

23 This current thematic issue of the Review focuses on case studies with both local and global dimensions by attempting to encourage discussion on several crucial questions concerning the reformulation of sovereignty and the complex ties between local, national and global players.

24 The new land rush is an extremely interesting field of study for social sciences. This issue outlines several areas of research that deserve further attention. The questions 
raised concern both social upheavals in different societies and future changes to the current world order.

\section{BIBLIOGRAPHIE}

ABÉLÈs M., Anthropologie de la globalisation, Paris, Payot, 2010.

« Amazonie : le Brésil ouvre les vannes de la déforestation », Le Point, 25 mai 2011 [en ligne], consulté en octobre 2011.

URL : http://www.lepoint.fr/monde/amazonie-le-bresil-ouvre-les-vannes-de-ladeforestation-25-05-2011-1335047_24.php

ANDRIANIRINA RATSIALONANA R., L. RAMAROJOHN, P. BURNOD et A. TEYSSIER, « Après Daewoo ? État des lieux et perspectives des appropriations à grande échelle à Madagascar ", étude CIRAD/ Observatoire du foncier Madagascar, 2010 (version provisoire) [en ligne], consulté en octobre 2011.

URL : www.observatoire-foncier.mg/get-file.php?id=70

BAYART J.-F., Le gouvernement du monde : une critique politique de la mondialisation, Paris, Fayard, 2004.

воттоN S., La multinationale et le bidonville. Privatisations et pauvreté à Buenos Aires, Paris, Karthala, 2007.

BURNOD P., W. ANSEEUW, P. M. BOSC, M. A. EVEN, « La menace de l'appropriation foncière à grande échelle », La revue durable, $\mathrm{n}^{\circ}$ 37, $2010: 27-29$.

ChaUVEaU J.-P., J.-P. Colin, J.-P. JACOB, P. LAVIGNe Delville et P. Y. LE MEUR, Modes d'accès a la terre, marchés fonciers, gouvernance et politiques foncières en Afrique de l'Ouest, résultats du projet de recherche Inco-Claims (Bénin, Burkina Faso, Côte d'Ivoire, Lali), Londres, IIED, 2006.

CHAUVEAU, J.-P. et J.-P. COLIN, « Customary transfers and land sales in Côte d'Ivoire: revisiting the embeddedness issue ", Africa, vol. 80, $\mathrm{n}^{\circ} 1,2010: 81-103$

COTULA L. and R. LEONARD, Investing in Partnership: Agricultural Investment and Collaborative Business Models. Highlights from an International Lesson-Sharing Workshop (Maputo, 17th-18th march 2010), London, IIED, 2010.

COUlATY A., « Mapouche, le droit à la terre », Altermondes, n 16, 2008 : 30-31.

DELAHAYE O., « La question agraire au Venezuela de 1493 aux années actuelles », Économie rurale, $\mathrm{n}^{\circ} 313-314,2009: 115-128$.

DUFFY R., « Non-governmental Organisations and Governance States: The impact of transnational Environmental Managment Networks in Madagascar ", Environmental Politics, vol. 15, n 5, 2006 : 731-749.

KARSENTY A., « Les acquisitions de terre à grande échelle ont-elles un avenir ? Les paysans doivent faire reconnaître leurs droits locaux pour rendre plus difficiles les allocations arbitraires de superficies ", Paysans, n 326, $2011: 1-10$. 
KELLER E., « Who are They? Local understandings of NGO and State Power in Masoala, Madagascar », Tsantsa, $n^{\circ} 14,2009:$ 76-85.

KULL C. A., Isle of Fire. The Political Ecology of Landscape Burning in Madagascar, Chicago, University of Chicago Press, 2004.

MARCHAL R., « Des contresens possibles de la globalisation : privatisation de l'État et bienfaisance au Soudan et au Somaliland », Politique africaine, $n^{\circ} 73,1999: 68-81$.

MONSUTTI A. et B. PETRIC (dir.), « Les nouvelles arènes politiques », Tsantsa, $n^{\circ}$ 14, numéro spécial, 2009.

MULLER B., « Comment rendre technique un débat politique : controverses autour des biotechnologies agricoles au sein de la FAO », Tsantsa, $n^{\circ}$ 14, $2009: 27-36$.

PETRIC B., «Le Kirghizstan : laboratoire de la nouvelle gouvernance mondiale », Revue Transitions, $\mathrm{n}^{\circ} 4,2006$.

RABESAHALA HORNING N., « Strong Support for Weak Performance: State and Donor's Mutual Dependance in Madagascar », Africa Affairs, vol. 107, n² 428, 2008 : 405-431.

SATURNINO M., Jr. BORRAS, R. Hall, I. SCOONES, B. WHITE and W. WOLFORD, « Towards a better Understanding of Global Land Grabbing: an editorial introduction ", Journal of Peasant Studies, vol. 38, issue 2, 2011 : 209-216.

STEIN T. H., K. OTSUKA and F. PLACE (ed.), The Emergence of Land Markets in Africa: Impacts on Poverty, Equity, and Efficiency, Washington, Resources for the Future, 2009.

TEYSSIER A., L. RAMAROJOHN et R. ANDRIANIRINA RATSIALONANA, « Des terres pour l'agro-industrie internationale ? Un dilemme pour la politique foncière malgache », EchoGéo [en ligne], n 11, 2010, consulté en octobre 2011.

URL : http://echogeo.revues.org/11649.

\section{NOTES}

1. «Les indiens Mapouche contre la firme Benetton », publié dans l'hebdomadaire Le Point du 10/02/2011.

2. http://farmlandgrab.org/cat/show/237

3. Financial Times, 19 November 2008

4. Source: UN, World Food Programme, annual report, 2007.

5. http://www.chemonics.com/

6. Mediapart, "la chasse aux terres du sud est ouverte," (hunting season is open for land in developing countries) 26 February 2009

7. Cf. A. Marant, Planète à vendre (Planet for Sale), documentary, Capa Production, Arte, May 2011. 


\section{AUTEUR}

\section{BORIS PETRIC}

CNRS-EHESS LAIOS, chargé de mission à la FMSH

bpetric@msh-paris.fr 